\title{
Effects of dietary energy and crude protein levels on growth performance, blood profiles, and nutrient digestibility in weaning pigs
}

\author{
Lin Hu Fang', Ying Hai Jin², Sung Ho Do ${ }^{1}$, Jin Su Hong ${ }^{1}$, Byung Ock Kim¹, Tae Hee Han', and Yoo Yong Kim,*
}

\section{* Corresponding Author: Yoo Yong Kim Tel: +82-2-880-4801, Fax: +82-2-878-5839, \\ E-mail: yooykim@snu.ac.kr}

'School of Agricultural Biotechnology, and Research Institute of Agriculture and Life Sciences, Seoul National University, Seoul 08826, Korea

2 Department of Animal Science, Yanbian University, Yan Ji, Ji Lin, 133000 China

ORCID

Lin Hu Fang

https://orcid.org/0000-0002-3617-7583

Ying Hai Jin

https://orcid.org/0000-0002-6925-3183

Sung Ho Do

https://orcid.org/0000-0002-5465-8292

Jin Su Hong

https://orcid.org/0000-0002-3401-3024

Byung Ock Kim

https://orcid.org/0000-0001-8952-617X

Tae Hee Han

https://orcid.org/0000-0001-5950-7103

Yoo Yong Kim

https://orcid.org/0000-0001-8121-3291

Submitted Apr 17, 2018; Revised Jun 6, 2018; Accepted Aug 8, 2018
Objective: This experiment was conducted to investigate the effect of reducing dietary metabolic energy (ME) and crude protein (CP) levels on growth performance, blood profiles, and nutrient digestibility in weaning pigs.

Methods: A total of 240 crossbred pigs (Duroc $\times$ [Landrace $\times$ Yorkshire]) with an average body weight of $8.67 \pm 1.13 \mathrm{~kg}$ were used for a 6 -week feeding trial. Experimental pigs were allotted to a $2 \times 3$ factorial arrangement using a randomized complete block design. The first factor was two levels of dietary ME density (low ME level, $13.40 \mathrm{MJ} / \mathrm{kg}$ or high ME level, 13.82 $\mathrm{MJ} / \mathrm{kg}$ ) and the second factor was three dietary CP levels based on subdivision of early and late weaning phases (low CP level, 19.7\%/16.9\%; middle CP level, 21.7\%/18.9\%; or high CP level, $23.7 \% / 20.9 \%)$.

Results: Over the entire experimental period, there were no significant difference in body weight among groups, but a decrease in diet energy level was associated with an increase in average daily feed intake $(\mathrm{p}=0.02)$ and decrease in gain-feed ratio $(\mathrm{G}: \mathrm{F})$ ratio $(\mathrm{p}<0.01)$. Decreased CP levels in the diet were associated with a linear increase in average daily gain $(\mathrm{p}<$ $0.05)$ and quadratic increase in G:F ratio $(\mathrm{p}<0.05)$. In the early weaning period, blood urea nitrogen concentration tended to increase when $\mathrm{ME}$ in the diet decreased and decrease when $\mathrm{CP}$ level in the diet decreased ( $\mathrm{p}=0.09, \mathrm{p}<0.01$, respectively). Total protein concentration tended to increase when $\mathrm{CP}$ level was reduced $(\mathrm{p}=0.08)$. In the late weaning period, blood urea nitrogen concentration decreased linearly as $\mathrm{CP}$ level decreased $(\mathrm{p}<0.01)$. The $\mathrm{CP}$ and crude fat digestibility decreased when ME was decreased by $0.42 \mathrm{MJ} / \mathrm{kg}(\mathrm{p}=0.05, \mathrm{p}=0.01$, respectively). The CP digestibility increased linearly as $\mathrm{CP}$ level decreased $(\mathrm{p}=0.01)$.

Conclusion: A weaning pig diet containing high ME level (13.82 MJ/kg) and low CP level $(19.7 \% / 16.9 \%)$ can improve pig growth performance and nutrient digestibility.

Keywords: Energy; Crude Protein; Growth Performance; Blood Profiles; Nutrient Digestibility; Weaning Pigs

\section{INTRODUCTION}

Nutritional concentration of feed is very important in the swine industry as it affects both growth performance and profitability. Lower nutritional concentrations can decrease the growth rate of pigs, while higher concentrations can have a negative effect on the environment and increase production costs [1-3]. After weaning, piglets experience nutritional, physiological, environmental, and social stresses [4], which are linked to low feed intake, poor growth, and incidence of diarrhea [5]. In general, a high feed intake could increase the health of weaning pigs and improve growth performance [6,7].

Energy concentration in feed is an important factor of feed intake, as a high energy level can decrease feed intake, while a lower energy level can decrease the deposition of protein 
[8]. Deposition and intake of protein and amino acids is related to energy concentration [9]. However, the optimal energy requirements of weaning pigs are difficult to determine accurately [10], because different average daily feed intake (ADFI) and weaning stress. Metabolizable energy (ME) requirements in editions of NRC differ, with an increased in ME from 1998 to $2012[9,11]$. However, other studies were reported that ME levels in diets did not affect growth performance in weaning pigs $[12,13]$. In general, fat and oil are important energy sources in pig diets [14], but weaning pigs do not utilize fat and oil very efficiently [8].

In addition, recommended total $\mathrm{N}$ levels have decreased largely over the years in editions of NRC (1998 to 2012). However, other studies reported that the pigs fed low crude protein (CP) diet, showed better fecal consistency score, improved enteric health and growth performance [15-18]. Decreasing the protein level in feed can decrease the risk of post-weaning diarrhea, as undigested proteins can be utilized by pathogenic bacteria such as enterotoxigenic Escherichia coli [19]. Moreover, Jensen et al [20] reported that from birth to 56 days, the digestive enzymes of piglets have low activity for digestion of energy and protein. That means there is much more surplus protein and energy that cannot be digested in diets for piglets than requirement. Other study reported that digestibility of $\mathrm{CP}$ at the terminal ileum was from $60 \%$ to $80 \%$ in weaning pigs [21]. Hence, optimizing energy and protein levels in the weaning pig diet is therefore important.

For these many reasons, this experiment was conducted to investigate the effect of reducing dietary $\mathrm{ME}$ and $\mathrm{CP}$ levels on growth performance, blood profiles, and nutrient digestibility in weaning pigs.

\section{MATERIALS AND METHODS}

\section{Experimental animals and management}

All experimental procedures involving animals were conducted in accordance with the Animal Experimental Guidelines provided by the Seoul National University Institutional Animal Care and Use Committee (SNUIACUC; SNU-160819-9). A total of 240 crossbred pigs (Duroc $\times$ [LandracexYorkshire]) with an average body weight (BW) of $8.67 \pm 1.13 \mathrm{~kg}$ were used for a 6-week feeding trial. Pigs were reared at Seoul National University experimental farm. Weaning pigs were allotted to one of six treatments with five replications with 8 pigs per pen. Four male pigs and four female pigs were assigned to each pen of a weaning facility based on $\mathrm{BW}$, and pigs in each pen were maintained until the end of the experiment. Pigs were randomly allotted to their respective treatments by an experimental animal allotment program [22]. Pigs were reared in weaning $(1.54 \times 1.96 \mathrm{~m})$ facilities for 6 weeks. Feed and water were provided ad libitum during the entire experimental period by a 4-hole stainless feeder and two nipples installed in each pen.
The BW and feed intake were recorded at 0,3 , and 6 weeks to calculate average daily gain (ADG), ADFI, and gain-feed ratio (G:F ratio).

\section{Experimental design and diet}

Experimental pigs were allotted to a $2 \times 3$ factorial arrangement using a randomized complete block design. The first factor was two levels of dietary ME density (low ME level, 13.40 $\mathrm{MJ} / \mathrm{kg}$ or high ME level, $13.82 \mathrm{MJ} / \mathrm{kg}$ ) and the second factor was three dietary CP levels based on subdivision of weaning phases (low CP level, middle CP level, or high CP level), early weaning phase $\mathrm{CP}$ percentages of $23.7 \%, 21.7 \%$, and $19.7 \%$ and late weaning phase percentages of $20.9 \%, 18.9 \%$, and $16.9 \%$.

Experimental diets were formulated for two phases, namely early weaning phase (0 to 3 weeks) and late weaning phase (4 to 6 weeks). Formulae and chemical compositions of the experimental diet are provided in Table 1, 2 .

\section{Blood analysis}

Blood samples were taken from the jugular vein of six randomly selected pigs in each treatment when BW were recorded to measure blood urea nitrogen (BUN), glucose, albumin, and total protein after a 3 hours fasting. All blood samples were collected in serum tubes (SST II Advance, BD Vacutainer, Becton Dickinson, Plymouth, UK). Collected blood samples were centrifuged for $15 \mathrm{~min}$ at $3,000 \mathrm{rpm}$ at $4^{\circ} \mathrm{C}$ (5810R, Eppendorf, Hamburg, Germany). Serum was carefully transferred to 1.5 $\mathrm{mL}$ plastic tubes and stored at $-20^{\circ} \mathrm{C}$ until analysis. Total BUN (kinetic UV assay, Roche, Mannheim, Germany), albumin (Cobas 8000, Roche, Germany), and glucose (enzymatic kinetic assay, Roche, Germany) concentrations were analyzed using a blood analyzer. Total protein concentration was measured by a kinetic colorimetry assay using a blood analyzer (Modular Analytics, PE, Roche, Germany).

\section{Digestibility trial}

A digestibility trial was conducted using a completely randomized design with three replicates. A total of 18 weaning barrows ([Yorkshire $\times$ Landrace] $\times$ Duroc) with an average BW of 13.94 \pm $1.64 \mathrm{~kg}$ were individually allotted to an individual metabolic crate $(0.4 \times 0.8 \times 0.9 \mathrm{~m})$. A 5 -day adaptation period was followed by 5 days of data collection.

The daily feed allowance required to provide 2.6 times the maintenance requirements for ME $[106 \mathrm{kcal} \mathrm{ME} / \mathrm{kg}(0.44$ $\mathrm{MJ} / \mathrm{kg}$ ) of $\left.\mathrm{BW}^{0.75}\right]$ was calculated $[9,23]$. Experimental diets were provided during the late weaning phase at 07:00 and 19:00. At the first and last feeding, $1 \%$ ferric oxide and chromium oxide were added to the experimental diet. Water was provided ad libitum. Excreta and urine were collected daily and preserved at $-20^{\circ} \mathrm{C}$ until later analysis. When collection was finished, the excreta were dried in an air-forced drying oven at $60^{\circ} \mathrm{C}$ for $96 \mathrm{~h}$, and ground into $5 \mathrm{~mm}$ particles in a Wiley mill for 
Table 1. Formulae and chemical compositions of the diets of early weaning pigs

\begin{tabular}{|c|c|c|c|c|c|c|}
\hline \multirow{2}{*}{ Items } & \multicolumn{3}{|c|}{ Low energy ${ }^{1)}$} & \multicolumn{3}{|c|}{ High energy ${ }^{1)}$} \\
\hline & Low CP $(\%)^{2)}$ & Middle CP $(\%)^{2)}$ & High CP $(\%)^{2)}$ & Low CP $(\%)^{2)}$ & Middle CP $(\%)^{2)}$ & High CP $(\%)^{2)}$ \\
\hline \multicolumn{7}{|l|}{ Ingredient (\%) } \\
\hline Soybean meal & 21.82 & 27.36 & 32.84 & 22.37 & 27.82 & 33.27 \\
\hline Barley & 33.48 & 32.76 & 31.96 & 32.88 & 32.27 & 31.67 \\
\hline Whey powder & 8.00 & 8.00 & 8.00 & 8.00 & 8.00 & 8.00 \\
\hline Soypeptide & 4.54 & 4.74 & 5.00 & 4.46 & 4.72 & 5.00 \\
\hline Soy-oil & 0.00 & 0.00 & 0.00 & 2.18 & 2.18 & 2.18 \\
\hline Mono-dicalcium phosphate & 1.25 & 1.14 & 1.05 & 1.27 & 1.17 & 1.07 \\
\hline Limestone & 0.93 & 0.95 & 0.97 & 0.92 & 0.94 & 0.96 \\
\hline L-lysine-HCl, 78\% & 0.39 & 0.20 & 0.01 & 0.39 & 0.20 & 0.00 \\
\hline Salt & 0.30 & 0.30 & 0.30 & 0.30 & 0.30 & 0.30 \\
\hline $\mathrm{ZnO}$ & 0.05 & 0.05 & 0.05 & 0.05 & 0.05 & 0.05 \\
\hline \multicolumn{7}{|c|}{ Chemical composition (calculated value) } \\
\hline Metabolic energy (MJ/kg) & 13.40 & 13.40 & 13.40 & 13.82 & 13.82 & 13.82 \\
\hline Crude protein (\%) & 19.70 & 21.70 & 23.70 & 19.70 & 21.70 & 23.70 \\
\hline Total lysine (\%) & 1.35 & 1.35 & 1.35 & 1.35 & 1.35 & 1.35 \\
\hline Total methionine (\%) & 0.35 & 0.35 & 0.35 & 0.35 & 0.35 & 0.35 \\
\hline Total threonine (\%) & 0.89 & 0.89 & 0.89 & 0.89 & 0.89 & 0.89 \\
\hline Calcium (\%) & 0.80 & 0.80 & 0.80 & 0.80 & 0.80 & 0.80 \\
\hline Total phosphorus (\%) & 0.65 & 0.65 & 0.65 & 0.65 & 0.65 & 0.65 \\
\hline
\end{tabular}

$\mathrm{CP}$, crude protein; $\mathrm{ME}$, metabolic energy.

1) Low energy level, ME (13.40 MJ/kg); high energy level, ME (13.82 MJ/kg).

2) Low CP level: early weaning phase CP percentages of $19.7 \%$ and late weaning phase percentages of $16.9 \%$; middle CP level: early weaning phase CP percentages of $21.7 \%$, and late weaning phase percentages of $18.9 \%$; high CP level: early weaning phase CP percentages of $23.7 \%$, and late weaning phase percentages of $20.9 \%$.

3) Provided per kg of diet. Vitamins per $\mathrm{kg}$ of complete diet: vitamin $\mathrm{A}, 8,000 \mathrm{IU}$; vitamin $\mathrm{D}_{3}, 1,800 \mathrm{IU}$; vitamin $\mathrm{E}, 60 \mathrm{IU}$; vitamin $\mathrm{K}_{3}, 2$ mg; thiamine, $2.00 \mathrm{mg}$; riboflavin, 7.0 mg; pantothenic acid, 25 mg; niacin, 27 mg; pyridoxine, $3 \mathrm{mg}$; d-biotin, $0.2 \mathrm{mg}$; folic acid, $1 \mathrm{mg}$; vitamin $\mathrm{B}_{12}, 0.03 \mathrm{mg}$.

4) Provided per kg of diet. Minerals per kg of complete diet: Se, 0.3 mg; l, 1 mg; Mn, 51.6 mg; Cu, 105 mg; Fe, 150 mg; Zn, 72 mg; Co, 0.5 mg.

chemical analysis.

\section{Statistical analyses}

All collected data were analyzed using least squares mean comparisons and evaluated using the general linear model procedure implemented in the statistical software package SAS (SAS Institute Inc., Cary, NC, USA). Every pen was considered one unit in the feeding trial, and individual pigs were the experimental units in the digestibility trial and when assessing blood profiles. Orthogonal polynomial contrasts were used to detect linear and quadratic responses to $\mathrm{CP}$ levels when the significance of $\mathrm{CP}$ was evaluated. Differences were declared significant at $\mathrm{p}<0.05$ or highly significant at $\mathrm{p}<0.01$, while $\mathrm{p} \geq$ 0.05 and $p<0.10$ was considered to indicate a trend in the data.

\section{RESULTS AND DISCUSSION}

\section{Growth performance}

The effect of dietary energy and CP levels on growth performance are presented in Table 3 . In the early weaning period, ADG (linear, $\mathrm{p}<0.01$ ) and ADFI (linear, $\mathrm{p}<0.05$ ) increased when diet $\mathrm{CP}$ level decreased, and ADFI increased when dietary $\mathrm{ME}$ decreased $(\mathrm{p}=0.04)$. In the late weaning period, $\operatorname{ADFI}(\mathrm{p}=0.03)$ increased and the G:F ratio $(\mathrm{p}<0.01)$ decreased when $\mathrm{ME}$ level was decreased by $0.42 \mathrm{MJ} / \mathrm{kg}$. There were no significant differences in BW over the experimental period, but decreased ME levels were associated with an increase in $\operatorname{ADFI}(p=0.02)$ and a decrease in G:F ratio $(p<0.01)$. A decrease in $\mathrm{CP}$ level resulted in a linear increase in $\mathrm{ADG}(\mathrm{p}<0.05)$ and a 
Table 2. Formulae and chemical compositions of diets in late weaning pigs

\begin{tabular}{|c|c|c|c|c|c|c|}
\hline \multirow{2}{*}{ Items } & \multicolumn{3}{|c|}{ Low energy ${ }^{1)}$} & \multicolumn{3}{|c|}{ High energy $^{1)}$} \\
\hline & Low CP $(\%)^{2)}$ & Middle CP $(\%)^{2)}$ & High CP $(\%)^{2)}$ & Low CP $(\%)^{2)}$ & Middle CP $(\%)^{2)}$ & High CP $(\%)^{2)}$ \\
\hline \multicolumn{7}{|l|}{ Ingredient (\%) } \\
\hline Soybean meal & 21.09 & 25.48 & 29.86 & 21.66 & 25.94 & 30.22 \\
\hline Barley & 25.65 & 25.50 & 25.44 & 25.04 & 25.10 & 25.17 \\
\hline Whey powder & 3.00 & 3.00 & 3.00 & 3.00 & 3.00 & 3.00 \\
\hline Soypeptide & 0.81 & 1.81 & 2.81 & 0.75 & 1.80 & 2.83 \\
\hline Soy-oil & 0.26 & 0.13 & 0.00 & 2.45 & 2.30 & 2.17 \\
\hline Mono-dicalcium phosphate & 1.22 & 1.12 & 1.02 & 1.25 & 1.13 & 1.03 \\
\hline Limestone & 0.82 & 0.84 & 0.85 & 0.81 & 0.83 & 0.85 \\
\hline L-lysine-HCl, $78 \%$ & 0.38 & 0.19 & 0.00 & 0.37 & 0.18 & 0.00 \\
\hline Salt & 0.30 & 0.30 & 0.30 & 0.30 & 0.30 & 0.30 \\
\hline $\mathrm{ZnO}$ & 0.03 & 0.03 & 0.03 & 0.03 & 0.03 & 0.03 \\
\hline \multicolumn{7}{|c|}{ Chemical composition (calculated value) } \\
\hline Metabolic energy (MJ/kg) & 13.40 & 13.40 & 13.40 & 13.82 & 13.82 & 13.82 \\
\hline Crude protein (\%) & 16.90 & 18.90 & 20.90 & 16.90 & 18.90 & 20.90 \\
\hline Total lysine (\%) & 1.15 & 1.15 & 1.15 & 1.15 & 1.15 & 1.15 \\
\hline Total methionine (\%) & 0.31 & 0.31 & 0.31 & 0.30 & 0.31 & 0.31 \\
\hline Total threonine (\%) & 0.80 & 0.80 & 0.80 & 0.80 & 0.80 & 0.80 \\
\hline Calcium (\%) & 0.70 & 0.70 & 0.70 & 0.70 & 0.70 & 0.70 \\
\hline Total phosphorus (\%) & 0.60 & 0.60 & 0.60 & 0.60 & 0.60 & 0.60 \\
\hline
\end{tabular}

$\mathrm{CP}$, crude protein; ME, metabolic energy.

1) Low energy level, ME (13.40 MJ/kg); high energy level, ME (13.82 MJ/kg).

2) Low CP level: early weaning phase CP percentages of $19.7 \%$ and late weaning phase percentages of $16.9 \%$; middle CP level: early weaning phase CP percentages of $21.7 \%$, and late weaning phase percentages of $18.9 \%$; high CP level: early weaning phase CP percentages of $23.7 \%$, and late weaning phase percentages of $20.9 \%$.

${ }^{3)}$ Provided per $\mathrm{kg}$ of diet. Vitamins per $\mathrm{kg}$ of complete diets: vitamin $\mathrm{A}, 8,000 \mathrm{IU}$; vitamin $\mathrm{D}_{3}, 1,800 \mathrm{IU}$; vitamin $\mathrm{E}, 60 \mathrm{IU}$; vitamin $\mathrm{K}_{3}, 2$ mg; thiamine, $2.00 \mathrm{mg}$; riboflavin, 7.0 mg; pantothenic acid, $25 \mathrm{mg}$; niacin, $27 \mathrm{mg}$; pyridoxine, $3 \mathrm{mg}$; d-biotin, $0.2 \mathrm{mg}$; folic acid, $1 \mathrm{mg}$; vitamin $\mathrm{B}_{12}, 0.03 \mathrm{mg}$.

4) Provided per kg of diet. Minerals per kg of complete diet: Se, 0.3 mg; l, 1 mg; Mn, 51.6 mg; Cu, 105 mg; Fe, 150 mg; Zn, 72 mg; Co, 0.5 mg.

quadratic increase in G:F ratio $(\mathrm{p}<0.05)$. Therefore, decreasing the ME level by $0.42 \mathrm{MJ} / \mathrm{kg}$ did not affect growth performance, and reducing the $\mathrm{CP}$ level by $4 \%$ improved $\mathrm{ADG}$ and the $\mathrm{G}: \mathrm{F}$ ratio.

The effect of dietary energy density on weaning pig performance is a topic of debate among researchers. Tokach et al [24] and Hastad et al [25] reported that decreasing dietary energy concentration had no effect on growth. Ribeiro et al [12] reported that reducing dietary ME from 3,700 kcal/ $\mathrm{kg}$ to 3,250 $\mathrm{kcal} / \mathrm{kg}(15.49 \mathrm{MJ} / \mathrm{kg}$ to $13.61 \mathrm{MJ} / \mathrm{kg})$ had no influence on growth performance. Beaulieu et al [10] reported that decreasing the digestible energy concentration from $3,650 \mathrm{kcal} / \mathrm{kg}$ to $3,350 \mathrm{kcal} / \mathrm{kg}(15.28 \mathrm{MJ} / \mathrm{kg}$ to $14.03 \mathrm{MJ} / \mathrm{kg})$ in the weaning $\mathrm{pig}$ diet increased BW, ADG, and ADFI linearly, while the G:F ratio decreased linearly.

In this study, reducing the soybean meal (SBM) level to decrease $\mathrm{CP}$ level improved growth performance over the whole experiment period. A similar result for $\mathrm{ADG}$ and G:F ratio was reported by Li et al [26,27]. Le Bellego and Noblet [28] described a reduction in $\mathrm{N}$ excretion and an increase in feed intake when CP level was reduced from $22.4 \%$ to $20.4 \%$. In other studies, a lower CP level had no negative effects on growth performance $[29,30]$. Hermes et al [29] reported that decreasing the $\mathrm{CP}$ level from $20 \%$ to $16 \%$ in the weaning pig (9 to 18 $\mathrm{kg}$ ) diet had no effect on growth performance after weaning for 3 weeks. Nyachoti et al [30] reported a significant reduction in $\mathrm{ADG}$ and $\mathrm{ADFI}$ for diets containing a CP level of 19\% or less. 
Table 3. Effects of dietary energy and crude protein levels on growth performance in weaning pigs

\begin{tabular}{|c|c|c|c|c|c|c|c|c|c|c|}
\hline \multirow{2}{*}{ Items } & \multicolumn{3}{|c|}{ Low energy ${ }^{1)}$} & \multicolumn{3}{|c|}{ High energy $^{1)}$} & \multirow{2}{*}{ SEM } & \multicolumn{3}{|c|}{$\mathrm{p}$-value } \\
\hline & Low CP $(\%)^{2)}$ & Middle CP $(\%)^{2)}$ & High CP $(\%)^{2)}$ & Low CP $(\%)^{2)}$ & Middle CP $(\%)^{2)}$ & High CP $(\%)^{2)}$ & & ME & $\mathrm{CP}$ & $\mathrm{M} \times \mathrm{C}$ \\
\hline \multicolumn{11}{|c|}{ Body weight $(\mathrm{kg})$} \\
\hline Initial & 8.66 & 8.66 & 8.67 & 8.67 & 8.67 & 8.67 & 0.206 & 0.99 & 1.00 & 1.00 \\
\hline 3 weeks & 13.59 & 12.23 & 12.88 & 13.33 & 12.23 & 12.34 & 0.280 & 0.65 & 0.22 & 0.93 \\
\hline 6 weeks & 24.28 & 22.24 & 23.45 & 24.52 & 22.54 & 22.94 & 0.406 & 0.99 & 0.16 & 0.90 \\
\hline \multicolumn{11}{|l|}{ ADG $(g)$} \\
\hline $0-3$ weeks $^{3)}$ & $234^{a}$ & $170^{c}$ & $201^{b}$ & $222^{a}$ & $170^{c}$ & $175^{c}$ & 7.6 & 0.33 & $<0.01$ & 0.72 \\
\hline 4-6 weeks & 509 & 477 & 505 & 533 & 491 & 505 & 7.8 & 0.41 & 0.17 & 0.84 \\
\hline 0-6 weeks ${ }^{3)}$ & 372 & 323 & 352 & 377 & 330 & 340 & 6.5 & 0.99 & 0.01 & 0.76 \\
\hline \multicolumn{11}{|l|}{ ADFI (g) } \\
\hline $0-3$ weeks $^{3)}$ & $433^{\mathrm{a}}$ & $362^{b}$ & $388^{b}$ & $391^{b}$ & $335^{c}$ & $325^{c}$ & 10.6 & 0.04 & 0.01 & 0.84 \\
\hline 4-6 weeks & 986 & 970 & 1,030 & 924 & 925 & 915 & 16.7 & 0.03 & 0.82 & 0.66 \\
\hline 0-6 weeks & 709 & 666 & 704 & 658 & 630 & 620 & 11.9 & 0.02 & 0.44 & 0.67 \\
\hline \multicolumn{11}{|l|}{ G:F ratio } \\
\hline 0-3 weeks & 0.542 & 0.462 & 0.528 & 0.569 & 0.508 & 0.548 & 0.0148 & 0.31 & 0.15 & 0.93 \\
\hline 4-6 weeks & $0.518^{\mathrm{ab}}$ & $0.498^{b}$ & $0.490^{b}$ & $0.576^{a}$ & $0.532^{\mathrm{ab}}$ & $0.554^{\mathrm{a}}$ & 0.0084 & $<0.01$ & 0.17 & 0.65 \\
\hline 0-6 weeks ${ }^{4)}$ & $0.524^{b}$ & $0.488^{c}$ & $0.502^{b c}$ & $0.575^{\mathrm{a}}$ & $0.526^{b}$ & $0.549^{a b}$ & 0.0080 & $<0.01$ & 0.04 & 0.91 \\
\hline
\end{tabular}

CP, crude protein; SEM, standard error of the mean; $M E$, metabolic energy; $A D G$, average daily gain; ADFI, average daily feed intake; G:F, gain-feed ratio.

1) Low energy level, ME (13.40 MJ/kg); high energy level, ME (13.82 MJ/kg).

${ }^{2)}$ Low CP level: early weaning phase CP percentages of $19.7 \%$ and late weaning phase percentages of $16.9 \%$; middle CP level: early weaning phase CP percentages of $21.7 \%$, and late weaning phase percentages of $18.9 \%$; high CP level: early weaning phase CP percentages of $23.7 \%$, and late weaning phase percentages of $20.9 \%$.

${ }^{3)}$ Linear response $(p<0.05)$ to dietary CP levels when a significant CP effect was detected.

4) Quadratic response $(p<0.05)$ to dietary $C P$ level when a significant $C P$ effect was detected.

${ }^{a b c}$ Means with different superscripts in the same row differ significantly $(p<0.05)$.

\section{Blood profiles}

Blood profiles during the feeding trial are presented in Table

4. The BUN concentration during the early weaning period tended to increase when $\mathrm{ME}$ decreased and decrease when $\mathrm{CP}$ decreased ( $\mathrm{p}=0.09, \mathrm{p}<0.01$, respectively). Total protein concentration tended to increase when $\mathrm{CP}$ levels decreased

Table 4. Effects of dietary energy and crude protein levels on blood profiles in weaning pigs

\begin{tabular}{|c|c|c|c|c|c|c|c|c|c|c|}
\hline \multirow{2}{*}{ Items } & \multicolumn{3}{|c|}{ Low energy ${ }^{1)}$} & \multicolumn{3}{|c|}{ High energy ${ }^{1)}$} & \multirow{2}{*}{ SEM } & \multicolumn{3}{|c|}{$p$-valve } \\
\hline & Low CP $(\%)^{2)}$ & Middle CP $(\%)^{2)}$ & High CP $(\%)^{2)}$ & Low CP $(\%)^{2)}$ & Middle CP $(\%)^{2)}$ & High CP $(\%)^{2)}$ & & ME & $\mathrm{CP}$ & $\mathrm{M} \times \mathrm{C}$ \\
\hline \multicolumn{11}{|l|}{ Albumin (g/L) } \\
\hline Initial & 39.83 & - & - & - & - & & & & & \\
\hline 3 weeks & 30.40 & 31.80 & 30.00 & 30.20 & 31.00 & 30.20 & 0.543 & 0.82 & 0.63 & 0.94 \\
\hline 6 weeks & $31.40^{b}$ & $30.00^{b}$ & $34.20^{\mathrm{a}}$ & $30.40^{b}$ & $32.60^{a b}$ & $25.80^{c}$ & 0.796 & 0.12 & 0.94 & 0.01 \\
\hline \multicolumn{11}{|c|}{ BUN (mmol/L) } \\
\hline Initial & 3.14 & - & - & - & - & & & & & \\
\hline 3 weeks ${ }^{3)}$ & $3.93^{b c}$ & $4.92^{b}$ & $5.51^{\mathrm{a}}$ & $2.37^{c}$ & $4.89^{b}$ & $4.85^{b}$ & 0.271 & 0.09 & $<0.01$ & 0.35 \\
\hline 6 weeks ${ }^{3)}$ & $2.75^{c}$ & $3.81^{\mathrm{b}}$ & $5.47^{\mathrm{a}}$ & $2.11^{c}$ & $3.46^{b}$ & $4.82^{\mathrm{ab}}$ & 0.266 & 0.13 & $<0.01$ & 0.92 \\
\hline \multicolumn{11}{|c|}{ Glucose (mmol/L) } \\
\hline Initial & 6.67 & - & - & - & - & & & & & \\
\hline 3 weeks & 5.11 & 5.42 & 4.83 & 5.29 & 5.11 & 5.18 & 0.112 & 0.74 & 0.65 & 0.49 \\
\hline 6 weeks & 5.51 & 5.24 & 5.59 & 5.39 & 5.79 & 5.25 & 0.094 & 0.86 & 0.92 & 0.16 \\
\hline \multicolumn{11}{|c|}{ Total protein (g/L) } \\
\hline Initial & 53.10 & - & - & - & - & & & & & \\
\hline 3 weeks & 51.84 & 51.61 & 49.02 & 50.81 & 51.78 & 46.21 & 0.758 & 0.21 & 0.08 & 0.60 \\
\hline 6 weeks & 56.38 & 54.63 & 59.39 & 54.61 & 55.24 & 54.63 & 0.649 & 0.12 & 0.38 & 0.23 \\
\hline
\end{tabular}

$\mathrm{CP}$, crude protein; SEM, standard error of the mean; ME, metabolic energy; BUN, blood urea nitrogen.

1) Low energy level, ME (13.40 MJ/kg); high energy level, ME (13.82 MJ/kg).

2) Low CP level: early weaning phase CP percentages of $19.7 \%$ and late weaning phase percentages of $16.9 \%$; middle CP level: early weaning phase CP percentages of

$21.7 \%$, and late weaning phase percentages of $18.9 \%$; high CP level: early weaning phase CP percentages of $23.7 \%$, and late weaning phase percentages of $20.9 \%$.

${ }^{3)}$ Linear response $(p<0.05)$ to dietary CP levels when a significant CP effect was detected.

abc Means with different superscripts in the same row differ significantly $(p<0.05)$. 
Table 5. Effects of dietary energy and crude protein levels on nutrient digestibility in weaning pigs

\begin{tabular}{|c|c|c|c|c|c|c|c|c|c|c|}
\hline \multirow{2}{*}{$\begin{array}{l}\text { Nutrient } \\
\quad \text { digestibility (\%) }\end{array}$} & \multicolumn{3}{|c|}{ Low energy ${ }^{1)}$} & \multicolumn{3}{|c|}{ High energy $^{1)}$} & \multirow[b]{2}{*}{ SEM } & \multicolumn{3}{|c|}{ p-valve } \\
\hline & $\begin{array}{c}\text { Low CP } \\
(\%)^{2)}\end{array}$ & $\begin{array}{c}\text { Middle CP } \\
(\%)^{2)}\end{array}$ & $\begin{array}{c}\underset{(\%)^{2)}}{\text { High CP }} \\
(\%)\end{array}$ & $\begin{array}{c}\text { Low CP } \\
(\%)^{2)}\end{array}$ & $\begin{array}{c}\text { Middle CP } \\
(\%)^{2)}\end{array}$ & $\begin{array}{c}\text { High } \\
\text { CP }(\%)^{2)}\end{array}$ & & ME & $\mathrm{CP}$ & $\mathrm{M} \times \mathrm{C}$ \\
\hline Dry matter & 88.01 & 87.87 & 88.24 & 89.12 & 88.66 & 88.51 & 0.727 & 0.88 & 0.81 & 0.91 \\
\hline Crude protein ${ }^{3)}$ & $87.81^{\mathrm{ab}}$ & $85.07^{b}$ & $84.24^{b}$ & $89.41^{\mathrm{a}}$ & $85.21^{b}$ & $85.11^{b}$ & 1.459 & 0.05 & 0.01 & 0.21 \\
\hline Crude ash & 71.19 & 72.31 & 71.21 & 70.90 & 71.64 & 73.14 & 0.773 & 0.21 & 0.27 & 0.31 \\
\hline Crude fat & $74.51^{b}$ & $73.41^{b}$ & $72.87^{b}$ & $78.74^{\mathrm{a}}$ & $76.15^{\mathrm{ab}}$ & $75.71^{\mathrm{ab}}$ & 1.181 & 0.01 & 0.18 & 0.87 \\
\hline
\end{tabular}

$\mathrm{CP}$, crude protein; SEM, standard error of the mean; $\mathrm{ME}$, metabolic energy.

1) Low energy level, ME (13.40 MJ/kg); high energy level, ME (13.82 MJ/kg).

2) Low CP level: early weaning phase CP percentages of $19.7 \%$ and late weaning phase percentages of $16.9 \%$; middle CP level: early weaning phase CP percentages of

$21.7 \%$, and late weaning phase percentages of $18.9 \%$; high CP level: early weaning phase CP percentages of $23.7 \%$, and late weaning phase percentages of $20.9 \%$.

${ }^{3)}$ Linear response $(p<0.05)$ to dietary CP levels when a significant CP effect was detected.

${ }^{a b}$ Means with different superscripts in the same row differ significantly $(p<0.05)$.

$(\mathrm{p}=0.08)$ in early weaning phase. In the late weaning period, BUN concentration decreased linearly as CP level decreased $(\mathrm{p}<0.01)$.

The BUN concentration is an indicator of protein utilization and affects amino acid balance and $\mathrm{N}$-intake [31,32]. Increased energy intake increases protein deposition [33]. This explains why in this study, BUN concentration increased when dietary ME level decreased. BUN concentration decreased when CP level decreased because of optimal amino acid balance and less $\mathrm{N}$-intake. Jeaurond et al [1] and Heo et al [34] reported consistent results with this study, BUN and plasma urea nitrogen concentration decreased when $\mathrm{CP}$ level in the weaning pig diet was reduced.

Blood total protein level was increased when pig protein utilization increased [35]. In this study, blood total protein level tended to increase when dietary CP level decreased in weaning pig diet. Also, ADG was increased when dietary $\mathrm{CP}$ level deceased. Results in this study indicate that low CP level (19.7\%) in the early weaning pig diet is an optimal CP level.

\section{Nutrient digestibility}

Differences in dietary energy and CP levels in the weaning pig diet resulted in significant differences in protein digestibility (Table 5). The CP and crude fat ( $\mathrm{p}=0.05, \mathrm{p}=0.01$, respectively) digestibility decreased when the ME was decreased by 0.42 $\mathrm{MJ} / \mathrm{kg}$. The $\mathrm{CP}$ digestibility increased in a linear manner when the $\mathrm{CP}$ level in the diet decreased $(\mathrm{p}=0.01)$.

This experiment decreased dietary ME concentration by reducing the soy oil content of the feed. Consequently, crude fat digestibility decreased by $3 \%$ to $4 \%$ when ME in the diet was reduced to $0.42 \mathrm{MJ} / \mathrm{kg}$. Energy digestibility are affected by the type and proportion of ingredients as well as energy source in the diet [10]. Nam and Aherne [36] and the NRC [9] reported that total energy intake could be similar despite different feed intakes because of variations in the energy density of the diet. The ability to digest fat is limited in pigs for the first 35 days of life, but increases after 42 days [10]. Fat digestibility in this experiment results obtained for the late weaning period are in agreement with those of Tokach et al [24] and Beaulieu et al [10].

Lawrence et al [37] and Smith et al [38] reported that dietary energy level affected various nutritional responses. Energy intake is known to influence protein deposition [39]. Lawrence et al [37] and Beaulieu et al [10] reported that the amount of energy in the feed could change $\mathrm{N}$-retention to increase protein digestibility. The results in this study are similar to those if Van Lunen and Cole [40] that decreasing energy density could reduce protein and lipid gain.

The main determinants of protein digestibility are the level and balance of essential amino acids and the animal's requirement [41]. In this study, lysine \%, methionine \%, and threonine $\%$ were the same for different $\mathrm{CP}$ treatments. In other words, although $\mathrm{CP}$ levels in the diet were reduced, but the limiting amino acid content was not. In this study, CP digestibility increased when dietary $\mathrm{CP}$ levels were decreased. Reducing the $\mathrm{CP}$ level without changing the levels of limiting amino acids can result in a more optimal amino acid composition than a high CP level.

\section{CONCLUSION}

Decreasing the energy content of the weaning pig diet by 0.42 $\mathrm{MJ} / \mathrm{kg}(13.82 \mathrm{MJ} / \mathrm{kg}$ to $13.40 \mathrm{MJ} / \mathrm{kg}$ ) had no effects on growth performance, but decreased fat and protein digestibility. In addition, reducing $\mathrm{CP}$ level by $4 \%$ improved growth performance and the digestibility of proteins, and decreased the BUN level.

A weaning pig diet containing high ME level (13.82 MJ/kg) and low CP level (19.7\%/16.9\%) can improve pig growth performance and nutrient digestibility.

\section{CONFLICT OF INTEREST}

We certify that there is no conflict of interest with any financial 
organization regarding the material discussed in the manuscript.

\section{ACKNOWLEDGMENTS}

This work was carried out with the support of the Cooperative Research Program for Agriculture Science \& Technology Development (Project No. PJ011617), Rural Development Administration, Korea.

\section{REFERENCES}

1. Jongbloed AW, Lenis N. Alteration of nutrition as a means to reduce environmental pollution by pigs. Livest Prod Sci 1992; 31:75.

2. Paik IK, Blair R, Jacob J. Strategies to reduce environmental pollution from animal manure: principles and nutritional management - a review -. Asian-Australas J Anim Sci 1996;9:615-36.

3. Jeong TS, Heo PS, Lee GY, et al. The influence of phase feeding methods on growth performance, meat quality, and production cost in growing-finishing pigs. J Anim Sci Technol 2010;52: 29-36.

4. Pluske JR. Nutrition of the neonatal pig. In: Varley MA, editors. The neonatal pig: development and survival. Wallingford, UK: CAB International; 1995. 206 p.

5. Gatnau R. Plasma protein in diets for weaning pigs. Int. Pig Topics 1999;14:7-9.

6. Makkink CA. Of pigs, dietary proteins, and pancreatic proteases [dissertation]. Wageningen, The Netherlands: Wageningen Agricultural University; 1993.

7. McCracken BA, Gaskins HR, Ruwe-Kaiser PJ, Klasing KC, Jewell DE. Diet-dependent and diet-independent metabolic responses underlie growth stasis of pigs at weaning. J Nutr 1995; 125:2838-45.

8. Swine nutrition. 2th ed. In: Lewis AJ, Southern LL, editors. Boca Raton London New York Washington, DC: CRC Press; 2001.

9. Committee on Nutrient Requirements of Swine, National Research Council. Nutrient requirements of swine. 10th ed. Washington, DC, USA: National Academy Press; 1998.

10. Beaulieu AD, Levesque CL, Patience JF. The effects of dietary energy concentration and weaning site on weanling pig performance. J Anim Sci 2006;84:1159-68.

11. Committee on Nutrient Requirements of Swine, National Research Council. Nutrient requirements of swine. 11th ed. Washington, DC, USA: National Academy Press; 2012.

12. Ribeiro AML, Farina G, Vieira MS, Perales VA, Kessler AM. Energy utilization of light and heavy weaned piglets subjected to different dietary energy levels. R Bras Zootec 2016;45:532-9.

13. Lee JH, Kim HB, Yun W, et al. Effects of reducing dietary crude protein and metabolic energy in weaned piglets. S Afr J Anim Sci 2017;47:574-81.

14. Bajao NC, Lara LJC. Oil and fat in broiler nutrition. Braz J Poult
Sci 2005;7:3:129-41.

15. Opapeju FO, Krause DO, Payne RL, Rademacher M, Nyachoti CM. Effect of dietary protein level on growth performance, indicators of enteric health, and gastrointestinal microbial ecology of weaned pigs induced with postweaning colibacillosis. J Anim Sci 2009;87:2635-43.

16. Opapeju FO, Roriguez-Lecompte JC, Rademacher M, Krause DO, Nyachoti CM. Low crude protein diets modulate intestinal responses in weaned pigs challenged with Escherichia coli K88. Can J Anim Sci 2015;95:71-8.

17. Wen XL, Wang L, Zheng CT, et al. Fecal scores and microbial metabolites in weaned piglets fed different protein sources and levels. Anim Nutr 2018;4:31-6.

18. Wu YP, Jiang ZY, Zheng CT, et al. Effects of protein sources and levels in antibiotic-free diets on diarrhea, intestinal morphology, and expression of tight junctions in weaned piglets. Anim Nutr 2015;1:170-6.

19. Wellock IJ, Fortomaris PD, Houdijk JGM, Kyriazakis I. Effects of dietary protein supply, weaning age and experimental enterotoxigenic Escherichia coli infection on newly weaned pigs: health. Animal 2008;2:834-42.

20. Jensen MS, Jensen SK, Jakobsen K. Development of digestive enzymes in pigs with emphasis on lipolytic activity in the stomach and pancreas. J Anim Sci 1997;24:437-45.

21.Högberg A, Lindberg JE. Influence of cereal non-starch polysaccharides and enzyme supplementation on digestion site and gut environment in weaned piglets. Anim Feed Sci Technol 2004:116:113-28.

22. Kim BG, Lindemann, MD. A new spreadsheet method for the experimental animal allotment. J Amin Sci 2007;85(Suppl. 2):112.

23. Kiarie E, Nyachoti CM, Slominski BA, Blank G. Growth performance, gastrointestinal microbial activity, and nutrient digestibility in early-weaned pigs fed diets containing flaxseed and carbohydrase enzyme. J Anim Sci 2007;85:2982-93.

24. Tokach MD, Pettigrew JE, Johnston LJ, et al. Effect of adding fat and (or) milk products to the weanling pig diet on performance in the nursery and subsequent grow-finish stages. J Anim Sci 1995;73:3358-68.

25. Hastad CW, Tokach MD, Nelssen JL, Goodband RD, Dritz SS. Evaluation of ground corn germ as an energy source in nursery diets. In: Kansas State Swine Day. Manhattan, KS, USA: Kansas State University; 2001. 45 p.

26.Li DF, Nelssen JL, Reddy PG, et al. Measuring suitability of soybean meal products for early-weaned pigs with immunological criteria. J Anim Sci 1991;69:3299-307.

27.Li DF, Nelssen JL, Reddy PG, et al. Interrelationship between hypersensitivity to soybean proteins and growth performance in early weaned pigs. J Anim Sci 1991;69:4062-9.

28. Le Bellego L, Noblet J. Performance and utilization of dietary energy and amino acids in piglets fed low protein diets. Livest Prod Sci 2002;76:45-58. 
29. Hermes RG, Molist F, Ywazaki M, et al. Effect of dietary level of protein and fiber on the productive performance and health status of piglets. J Anim Sci 2009;87:3569-77.

30. Nyachoti CM, Omogbenigun FO, Rademacher M, Blank G. Performance responses and indicators of gastrointestinal health in early-weaned pigs fed low-protein amino acid-supplemented diets. J Anim Sci 2006;84:125-34.

31.Eggum BO, Chwalibog A, Danielsen V. The influence of dietary concentration of amino acids on protein and energy utilization in growing rats and piglets. 3. Diets of high biological value but with different protein concentrations. J Anim Physiol Anim Nutr 1987;57:52-64.

32. Whang KY, Easter RA. Blood urea nitrogen as an index of feed efficiency and lean growth potential in growing-finishing swine. Asian-Australas J Anim Sci 2000;13:811-6.

33. Fuller MF, Weekes TEC, Cadenhead A, Bruce JB. The proteinsparing effect of carbohydrate. 2. The role of insulin. Br J Nutr 1977;38:489-96.

34. Heo JM, Kim JC, Hansen F, et al. Effects of feeding low protein diets to piglets on plasma urea nitrogen, faecal ammonia nitrogen, the incidence of diarrhoea and performance after weaning. Arch Anim Nutr 2008;62:343-58.
35. Matthews JO, Gentry LR, Chapa AM, et al. Change in plasma metabolites and hormones in pigs relative to time of feeding. J Anim Sci 1998;76(Suppl 1):168.

36. Nam DS, Aherne FX. The effects of lysine:energy ratio on the performance of weanling pigs. J Anim Sci 1994;72:1247-56.

37. Lawrence BV, Adeola O, Cline TR. Nitrogen utilization and lean growth performance of 20 to 50 kilogram pigs fed diets balanced for lysine: energy ratio. J Anim Sci 1994;72:2887-95.

38.Smith JW, Tokach MD, Nelssen JL, Goodband RD. Effect of lysine: calorie ratio on growth performance of 10 to 25 kilogram pigs. J Anim Sci 1999;77:3000-6.

39. Whittemore CT, Fawcett RH. Theoretical aspects of a flexible model to stimulate protein and lipid growth in pigs. Anim Prod 1976; 22:87-96.

40.van Lunen TA, Cole DJA. The effect of dietary energy concentration and lysine/digestible energy ratio on growth performance and nitrogen deposition of young hybrid pigs. Anim Sci 1998;67:117-29.

41.Jin CF, Kim JH, Han IK, Bea SH. Effects of supplemental synthetic amino acids to the low protein diets on the performance of growing pigs. Asian-Australas J Anim Sci 1998;11:1-7. 